\title{
A rare extramedullary involvement in myeloma: lung parenchyma and association with unfavorable chromosomal abnormalities
}

\author{
Miyelom'da nadir bir ekstramedüller tutulum: Akciğer parankimi ve olumsuz \\ kromozomal anormalliklerle ilişkisi
}

\author{
Özlem Şahin Balçık¹, Murat Albayrak¹, Simten Dağdaş², Funda Ceran², Gülsüm Özet², \\ Funda Demirağ ${ }^{3}$, Osman Yokuş ${ }^{4}$ \\ 1 Department of Hematology, Oncology Education and Research Hospital, Ankara, Turkey \\ 2Department of Hematology, Numune Education and Research Hospital, Ankara, Turkey \\ ${ }^{3}$ Department of Pathology, Atatürk Chest Diseases and Chest Surgery Education and Research Hospital, Ankara, Turkey \\ ${ }^{4}$ Department of Hematology, Kayseri Education and Research Hospital, Kayseri, Turkey
}

\begin{abstract}
Although pulmonary complications developing secondary to lung infections and involvement in ribs occur frequently in multiple myeloma (MM), involvement of the lung parenchyma is quite rare. In clinical studies, the involvement of lung parenchyma has been found to be associated with unfavorable prognosis. Here, a MM case in whom involvement of lung parenchyma was accompanied by unfavorable prognostic cytogenetic markers is presented.

A 62-year-old male presented with complaint of cough, and heterogeneous hypodense mass was detected in thorax computerized tomography. The patient underwent bronchoscopic biopsy. Pathological examination revealed diffuse plasma cell infiltration staining with kappa immunohistochemically. In bone marrow biopsy, plasma cell infiltration was observed. In conventional cytogenetic examination, hypodiploidy was established. In cytogenetic examination carried out with fluorescence in situ hybridization, deletion (13q) was determined. In conclusion, in patients diagnosed with MM and presenting with pulmonary mass lesion, lung involvement associated with plasma cell infiltration should also be considered in the differential diagnosis. As overall survival is low in these cases, more aggressive treatment approaches such as high-dose treatment should be immediately considered. (Turk J Hematol 2010; 27: 109-12)

Key words: Myeloma, pulmonary involvement, prognostication, cytogenetics, molecular genetics, del(13q), hypodiploidy

Received: May 7, $2008 \quad$ Accepted: January 72009

\section{Özet}

Multipl miyelomda (MM) akciğer enfeksiyonları ve göğüs kafesi kemiklerinde tutuluma bağlı gelişen pulmoner komplikasyonlar sıkça görülmesine karşın, akciğer parankim tutulumu oldukça nadirdir. Yapılan klinik çalışmalarda akciğer parankim tutulumunun kötü prognoz ile ilişkisi bulunmuştur. Burada akciğer parankim tutulumuna olumsuz prognostik sitogenetik belirleyicilerin eşlik ettiği bir MM olgusu sunulmaktadır.
\end{abstract}

Address for Correspondence: Özlem Şahin Balçık, M.D., Fatih University Medical School Department of Hematology, Ankara, Turkey Phone: +90 3123216697 Office: +90 3123360909 E-mail: drozlembalcik@yahoo.com

doi:10.5152/tjh.2010.08 
Öksürük şikayeti ile başvuran 62 yaşında erkek olguya çekilen toraks tomografisinde; sağ orta lob düzeyinde heterojen hipodens kitle görünümü saptandı. Bronkoskopik biyopsi yapıldı. Patolojik incelemede immünhistokimyasal olarak kappa ile diffüz boyanma gösteren plazma hücre infiltrasyonu saptandı. Kemik iliği biyopsisinde plazma hücre infiltrasyonu görüldü. Konvansiyonel sitogenetik incelemede hipodiploidi saptandı. Fluorescence in situ hybridization ile yapılan sitogenetik incelemede delesyon (13q) tespit edildi. Sonuç olarak, akciğerde kitle lezyonu ile başvuran ve MM tanısı alan hastalarda ayırıcı tanıda MM a bağlı plazma hücre infiltrasyonu da düşünülmelidir. Bu olgular toplam sağ kalımları düşük olduğundan, yüksek doz tedavi gibi daha agresif tedavi yaklaşımlarına hızla yönlendirilmelidir. (Turk J Hematol 2010; 27: 109-12)

Anahtar kelimeler: Miyelom, akciğer tutulumu, prognoz, sitogenetik, moleküler genetik, del(13q), hipodiploidi

Geliş tarihi: 7 Mayıs 2008 Kabul tarihi: 7 Ocak 2009

\section{Introduction}

Multiple myeloma (MM) is a disease characterized by the proliferation of malignant plasma cells in bone marrow [1]. Recently, parallel to the developments in cytogenetics, it has been demonstrated that genetic abnormalities play an important part in the prognosis of MM as in other hematological and solid malignancies [2,3]. Conventional cytogenetics and fluorescence in situ hybridization (FISH) analysis contribute substantially to clinical follow-up at the stages of selection among treatment options and determination of prognosis. It has been shown that hypodiploidy and deletion (del) $13 q$ are independent unfavorable prognostic factors [4,5]. MM may progress with extramedullary involvement. It may occur in all lymph nodes, skin, liver and spleen, and less frequently in the kidney and dura mater $[1,6]$. More rarely, involvements of the orbita, muscle, skin, and pericardium are seen [7-9]. Diagnosis is made with the establishment of monoclonal plasma cells in the involved organ. The response of these cases even to quite aggressive treatment approaches is not satisfactory $[1,10]$. Plasma cell diseases presenting with pleural effusion and plasmacytoma in the lung have been described [11,12]. However, the involvement of lung parenchyma occurs rarely in MM [13-17].

\section{Case Report}

A 62-year-old male patient presented with the complaints of fever, cough, sputum, and nonhomogeneous density on chest radiography. The patient's characteristics are detailed in Table 1. Thoracic computed tomography (CT) revealed a heterogeneous hypodense mass appearance without air at the level of the right middle lobe (Figure 1). Bronchoscopic biopsy was carried out with the presumptive diagnosis of lung carcinoma. Pathological examination revealed strong and diffuse plasma cell infiltration staining with kappa immunohistochemically (Figures 2, 3). Chromogranin, neuron specific enolase, keratin and CD56 were applied to the bronchoscopic biopsy material; however, no staining was observed and carcinoid tumor was ruled out. With the establishment of plasma cell infiltration in the lung, the case was evaluated thoroughly for MM. Plasma cell infiltration staining diffusely and strongly with kappa immunohistochemically was seen in bone marrow trephine biopsy as well. In serum immunofixation electrophoresis, immunoglobulin (lg) A kappa, and in urine immunofixation electrophoresis, kappa light chain, were established. Serum IgA level was found to be $8.04 \mathrm{~g} / \mathrm{L}(0.70-4.00 \mathrm{~g} / \mathrm{L})$. Hypodiploidy was detected with conventional genetical examination. In FISH analysis, del(13q) was established in $16 \%$ of the cells examined. The case was regarded as stage IIIB according to prog-
Table 1. Patient characteristics

\begin{tabular}{|c|c|}
\hline Age & \\
\hline Sex & Male \\
\hline Hemoglobin (g/dl) & $9.1(14-17.5)$ \\
\hline Leukocyte (x109/L) & $7.1(4.4-11.3)$ \\
\hline Platelet (x109/L) & $179(150-450)$ \\
\hline Creatinine $(\mathrm{mg} / \mathrm{dl})$ & 3.27 (0.5-1.4) \\
\hline Calcium (mg/dl) & $15.1(8.4-10.0)$ \\
\hline Albumin* (g/dl) & $3.2(3.4-5)$ \\
\hline $\mathrm{LDH}^{*}(\mathrm{U} / \mathrm{L})$ & $154(125-243)$ \\
\hline $\mathrm{CRP}^{*}(\mathrm{mg} / \mathrm{L})$ & $49(0-5)$ \\
\hline Beta-2 microglobulin* (mg/L) & $16.9(0.6-2.5)$ \\
\hline
\end{tabular}

*: Serum

LDH: Lactate dehydrogenase; CRP: C-reactive protein.

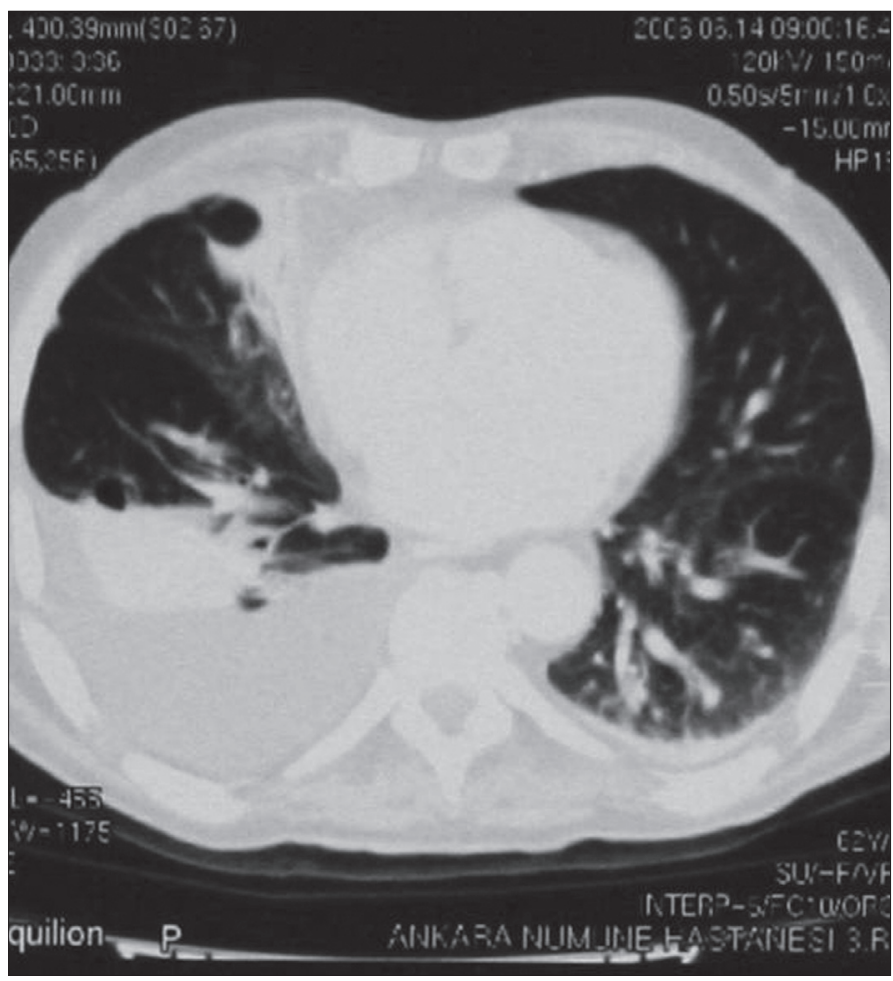

Figure 1. At the level of right middle lobe, heterogenous hypodense mass lesion in thorax computerized tomography 


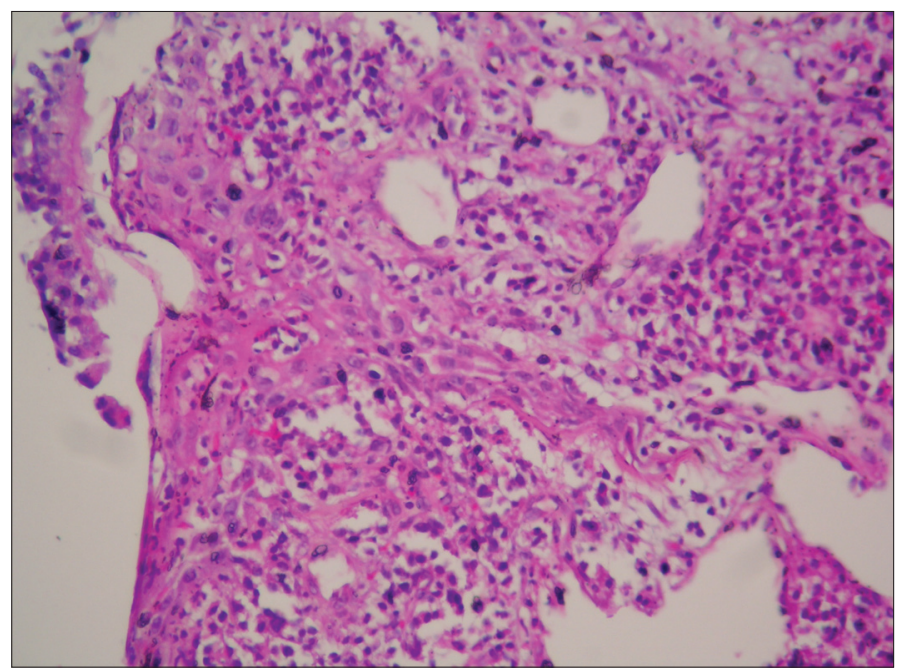

Figure 2. Plasma cell infiltration in the bronchial wall (HE X200)

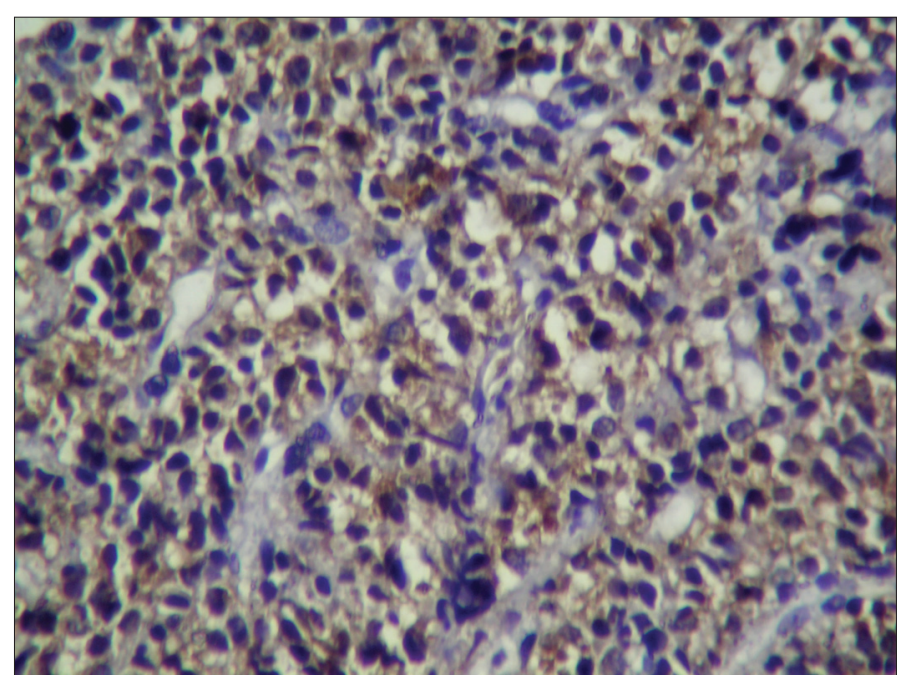

Figure 3. Plasma cells are positive with kappa light chain (Kappa X400)

nostic Durie Salmon staging system and stage III according to the International Staging System (ISS) for MM [18,19]. Chemotherapy including vincristine, adriablastin and dexamethasone was commenced. The patient did not respond to chemotherapy and died six months later due to progressive disease. All samples were drawn after obtaining formal written consent from the patient, and the case presentation was carried out in accordance with the Helsinki Declaration.

\section{Discussion}

In $\mathrm{MM}$, bone involvement in the thorax region and lung infections secondary to infections developing due to humoral immune deficiency related to hypogammaglobulinemia occur most frequently. Although pleural effusion and plasmacytoma in the lung are reported in association with $\mathrm{MM}$, lung parenchyma is a rare site of extramedullary involvement $[12,17]$. Pulmonary involvement in $\mathrm{MM}$ is associated with rapid progression of the disease. In the study of Oymak et al. [16] of 38 patients referring to the Chest Diseases
Department and being followed with the diagnosis of MM, thoracal involvement was established in 19 (50\%), lung involvement in 13 (35\%) and thoracal bone invasion in 9 (24\%). When the cases were evaluated according to their clinical and radiological findings, pneumonic infiltration was observed in 6 , mass lesion in 2, multiple nodular lesions in 2 , and interstitial infiltration in 3. In two patients with nodular lung infiltration and mass lesion, malignant plasma cell infiltration was demonstrated with percutaneous lung biopsy, and in the patient with reticulonodular infiltration, it was shown with bronchoscopic lung biopsy. In cases with pulmonary involvement, rapidly progressive disease was established, especially with renal involvement and pathological bone fractures. Similarly, in our case, plasma cell infiltration was detected with the biopsy obtained from the endobronchial lesion with bronchoscopic approach. The fact that our patient with renal involvement did not respond to chemotherapy and subsequently died is compatible with the reports in the literature. In the study of Damaj et al. [10], extramedullary involvement was established in 19 of 432 MM cases and these cases were evaluated. Of the cases recalcitrant to standard dose chemotherapy and thalidomide treatment, 8 responded to high-dose treatment supplemented with stem cell. Disease progressed in the other cases even under treatment. After a follow-up period of 13 months, 6 of these 11 patients died; partial remission was achieved in 4 and progressive disease developed in 2. It has been concluded that extramedullary involvement is rare in $\mathrm{MM}$ and that if it is present, the response to treatment is limited and the disease has an unfavorable prognosis. MM is quite a heterogeneous disease in terms of prognosis. There are cases in which survival is as short as a few months, while other cases have been described as surviving for more than 10 years. Although the disease has a similar presentation in all cases, prognosis is quite variable. Therefore, various prognostic parameters have been described for use in patient monitoring. While mostly clinical and biochemical parameters were used previously, cytogenetic methods are also used at present. Our case, with involvement of lung parenchyma and unfavorable prognosis, was evaluated with respect to biochemical and cytogenetic characteristics. The disease was determined as stage IIIB according to prognostic Durie Salmon staging system and as stage III according to ISS, with unfavorable prognostic characteristics. In our case, hypodiploidy was found with conventional cytogenetic examination and del(13q) with $\mathrm{FISH}$ analysis [20-22]. However, to our knowledge, there is no study aiming to determine the cytogenetic properties of cases with lung parenchyma involvement. $\operatorname{Del}(13 \mathrm{q})$ and hypodiploidy are each independent negative prognostic parameters irrespective of other parameters. These cases should be evaluated in terms of cytogenetic characteristics. Thus, accompanying cytogenetic abnormalities can be identified and the necessary steps may be taken for targeting treatment.

In the literature, there are reports on the association of lung parenchyma involvement with unfavorable prognosis $[10,16]$. In our case, identification of del(13q) and hypodiploidy as well 
as the other negative prognostic parameters and rapid progression of the disease with no treatment response are consistent with the literature.

In conclusion, in patients diagnosed with MM and presenting with pulmonary mass lesion, lung involvement associated with plasma cell infiltration should be kept in mind in the differential diagnosis. As the overall survival rate is low in these cases, more aggressive treatment approaches, such as highdose treatment, should be promptly considered.

\section{Conflict of interest}

No author of this paper has a conflict of interest, including specific financial interests, relationships, and/or affiliations relevant to the subject matter or materials included in this manuscript.

\section{References}

1. Tricot G. Multiple myeloma and other plasma cell disorders. In: Hoffman R, Benz EJ, Shattil SJ, Furie B, Cohen HJ, Silberstein LE et al., editors. Hematology Basic Principles and Practice. 4th ed. New York: Elsevier Churchill Livingstone, 2005:1501-21.

2. Dewald GW, Kyle RA, Hicks GA, Greipp PR. The clinical significance of cytogenetic studies in 100 patients with multiple myeloma, plasma cell leukemia or amyloidosis. Blood 1985;66:380-90.

3. Sawyer JR, Waldron JA, Jagannath S, Barlogie B. Cytogenetic findings in 200 patients with multiple myeloma. Cancer Genet Cytogenet 1995;82:41-9.

4. Smadja NV, Bastard C, Brigaudeau C, Leroux D, Fruchart C; Groupe Français de Cytogénétique Hématologique. Hypodiploidy is a major prognostic factor in multiple myeloma. Blood 2001;98:2229-38.

5. Fassas AB, Spencer T, Sawyer J, Zangari M, Lee CK, Anaissie E, Muwalla F, Morris C, Barlogie B, Tricot G. Both hypodiploidy and deletion of chromosome 13 independently confer poor prognosis in multiple myeloma. $\mathrm{Br} \mathrm{J}$ Haematol 2002;118:1041-7.

6. Haegelen C, Riffaud L, Bernard M, Carsin-Nicol B, Morandi X. Dural plasmacytoma revealing multiple myeloma. Case report. J Neurosurg 2006;104:608-10.

7. Thoumazet F, Donnio A, Ayeboua L, Brebion A, Diedhou A, Merle $\mathrm{H}$. Orbital and muscle involvement in multiple myeloma. Can J Ophthalmol 2006;41:733-6.

8. Alexandrescu DT, Koulova L, Wiernik PH. Unusual cutaneous involvement during plasma cell leukaemia phase in a multiple myeloma patient after treatment with thalidomide: a case report and review of the literature. Clin Exp Dermatol 2005;30:391-4.

9. Abelman W, Virchis A, Yong K. Extramedullary myeloma representing as a pericardial effusion with tamponade: two case reports and a further review of 19 cases in the literature. Mod Pathol 1995;8:257-9.
10. Damaj G, Mohty M, Vey N, Dincan E, Bouabdallah R, Faucher C, Stoppa AM, Gastaut JA. Features of extramedullary and extraosseous multiple myeloma: a report of 19 patients from a single center. Eur J Haematol 2004;73:402-6.

11. Rodríguez JN, Pereira A, Martínez JC, Conde J, Pujol E. Pleural effusion in multiple myeloma. Chest 1994;105:622-4.

12. Nonomura A, Mizukami $Y$, Shimizu J, Oda M, Watanabe $Y$, Kamimura R, Takashima T, Kitagawa M. Primary extramedullary plasmacytoma of the lung. Intern Med 1992;31:1396-400.

13. Kamble R, Rosenzweig T. Diffuse pulmonary parenchymal involvement in multiple myeloma: antemortem diagnosis. Int $J$ Hematol 2006;83:259-61.

14. Marmor DB, Farber JL, Gottlieb JE. Acute respiratory distress syndrome due to pulmonary involvement by neoplastic plasma cells in multiple myeloma. Thorax 2006;61:455-6.

15. Yokote T, Akioka T, Miyamoto H, Oka S, Hara S, Yamano T, Takasu T, Tsuji M, Hanafusa T.I. Pulmonary parenchymal infiltrates in a patient with CD20-positive multiple myeloma. Eur J Haematol 2005;74:61-5.

16. Oymak FS, Karaman A, Soyuer I, Karaman H, Gülmez I, Demir R, Unal A, Ozesmi M. Pulmonary and chest wall involvement in multiple myeloma. Tuberk Toraks 2003;51:27-32.

17. Luh SP, Lai YS, Tsai CH, Tsao TC. Extramedullary plasmacytoma (EMP): report of a case manifested as a mediastinal mass and multiple pulmonary nodules and review of literature. World $\mathrm{J}$ Surg Oncol 2007;5:123.

18. Durie BG, Salmon SE. A clinical staging system for multiple myeloma. Correlation of measured myeloma cell mass with presenting clinical features, response to treatment, and survival. Cancer 1975;36:842-54.

19. Greipp PR, San Miguel J, Durie BG, Crowley JJ, Barlogie B, Bladé J, Boccadoro M, Child JA, Avet-Loiseau H, Kyle RA, Lahuerta JJ, Ludwig H, Morgan G, Powles R, Shimizu K, Shustik C, Sonneveld P, Tosi P, Turesson I, Westin J. International staging system for multiple myeloma. J Clin Oncol 2005;23:3412-20.

20. Fassas AB, Ward S, Muwalla F, Van Hemert R, Schluterman K, Harik S, Tricot G. Myeloma of the central nervous system: strong association with unfavorable chromosomal abnormalities and other high-risk disease features. Leuk Lymphoma 2004;45:291-300.

21. Fassas AB, Muwalla F, Berryman $T$, Benramdane R, Joseph $L$, Anaissie E, Sethi R, Desikan R, Siegel D, Badros A, Toor A, Zangari M, Morris C, Angtuaco E, Mathew S, Wilson C, Hough A, Harik S, Barlogie B, Tricot G. Myeloma of the central nervous system: association with high-risk chromosomal abnormalities, plasmablastic morphology and extramedullary manifestations. Br J Haematol 2002;117:103-8.

22. Chang H, Sloan S, Li D, Keith Stewart A. Multiple myeloma involving central nervous system: high frequency of chromosome 17p13.1 (p53) deletions. Br J Haematol 2004;127:280-4. 